\title{
The Measurement Model of the Pharmacy Education Service Quality: An Empirical Quest Based on Two Approaches
}

\author{
Hemant Gupta ${ }^{1, *}$, Bhaveshkumar J Parmar² \\ ${ }^{1}$ Department of Marketing, Alliance Business School, Alliance University, Bangalore, Karnataka, INDIA. \\ ${ }^{2}$ Indukaka Ipcowala Institute of Management, Charotar University of Science and Technology, Gujarat, INDIA.
}

\begin{abstract}
Objectives: The objective of this study to build a comprehensive model to measure the service quality of the pharmaceutical institutes in India. At the same time, the author also validates the model with two different approaches of service quality measurement that belongs to gap score and perception-only measure. Materials and Methods: The eight pharmacy institutes are selected randomly from eastern India and then 370 respondents take part in this survey process. The model has been developed with exploratory and confirmatory factor analysis based on perception-only and gap (perception minus expectation) scores. Finally, the model has been validated with discriminate validation and OLS regression methods. Finding: The conclusion of this study belongs to a comprehensive model to measure the service quality of pharmacy institutes with the help of 14 variables under 4 latent factors of education service quality. This model may be applied to any pharmacy institute that is offering a graduate pharmacy program. Practical Application: For academician, this study provides a new comprehensive model which is applicable for any approach of measuring the service quality of pharmaceutical education institutes in India. Simultaneously, this model might provide a road map to the Government for improving the quality of education in the pharmacy education system.
\end{abstract}

Key words: Pharmacy education, Service Quality, SERVIQUAL, SERVIPERF, Indian Pharmacy Institutes.

\section{INTRODUCTION}

Service sectors are labor-intensive sectors and these having a high potential for employment generation. However, the sustainability of any service sector is dependent on its maintenance of quality. Hence, service quality is an important area of discussion in management literature. ${ }^{1}$ In the era of globalization, quality plays a significant role in order to accomplish a competitive advantage over competitors and maintain market leadership in the business world. In order to sustain and grow within the framework of an increasingly competitive market, organizations must adopt quality management practices. Strategically, retaining the unscaled service quality is basically deploying organizational resources and capabilities to nullify the threat of competition arising out from the business environment. Therefore, business organizations, particularly service organizations are now considering quality management practices. ${ }^{1}$

Like all other service industries, the education sector has a direct impact on society for social-economic growth and human resource development. Especially, higher education is acclaimed as one of the most important factors for national development. It also represents the major source of investment by individuals to contribute to national development. Once, Kazemi ${ }^{2}$ said that the glory of a community depends not only on the depth of higher education but also on the quantitative and qualitative development of an educational system.
Submission Date: 07-06-2021; Revision Date: 29-07-2021; Accepted Date: 10-09-2021.

DOI: 10.5530/ijper.55.4.195 Correspondence: Dr. Hemant Gupta Assistant Professor, Alliance Business School, Alliance University, Bangalore, Karnataka, INDIA. Phone: +91-9883244275, Email - hemant.bpm13@ gmail.com

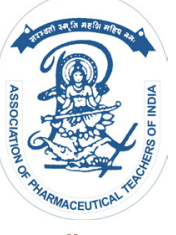

www.ijper.org 
Moreover, education only attaches the individual in contact with the values, but also it raises the functionality of the individual to the societal level. In this way, the educational system becomes a key factor in societal change. It has induced the capability of innovation, the willingness of cooperation and interconnection between communities.

Among the education service industry, technical education, particularly pharmaceutical education, has a direct bearing on society for health-specific economic development. One of the key skills required to a pharmacist is the ability to handle a patient in support of a doctor that satisfies patient by correct care, operation and control of disease condition. ${ }^{3}$ The substantial evolution in the pharmaceutical industry of developing nations has dramatically changed the role of pharmacy professionals from hospital pharmacists to patientcentric professionals. ${ }^{3}$ Globally, the traditional pharmaceutical course is primarily designed to conduct academic research with limited resources; however, the rapid innovation in the same industry enforces to produce the graduates with skills required for better employability. The researchers have observed the importance of pharmacy program in transforming the skill of students toward patient-centric professionals, who will work for society in the future. Thus, some researchers have opined that the pharmacy graduate program should not confine to the knowledge of pharmacy subject rather career orientation program also helps in the enhancement of the performance of pharmacy graduates. ${ }^{4}$

In this regard, the pharmacy educational institutes (PEIs) are playing an important role in transforming pharmacy education, research, and innovation for the sake of societal development. The structure of pharmaceutical education is not different from the current scenario of higher education institutes in India, which are competing for resources and quality. The resources like research funds, qualified faculties, and infrastructure affect the quality of the higher education system in developing countries. ${ }^{5}$ In India, the students have a wide range of options to prefer which institution to pursue their interests because of an increased number of institutes and university departments of pharmacy. Singh ${ }^{6}$ has referred to the absence of quality education and research facilities in the pharmacy institutes as one of the possible reasons behind the poor performs of the pharmacy institutes in India. Many other researchers ${ }^{7-11}$ have also opined similarly to Singh ${ }^{6}$ in different country contexts about pharmacy education. However, the course-specific feedback on the classroom experiences of the students is not sufficient for the assessment of the quality of pharmacy education. More systematic efforts are required to measure or examine the quality of education and the course content for the pharmacy program. However, this is considered to be a challenge for measuring the quality of the education service offered by HEIs. But despite all environmental challenges, it is necessary to measure the service quality of pharmacy education institutes for sustainable health-economic growth of a nation.

According to experts, students are to be considered as the primary customer ${ }^{5}$ where faculty members are service providers and both are significantly co-creators of the service delivered (training imparted) to former. Hence, understanding and measuring the service quality opinion of students is highly solicited. ${ }^{12}$

All these facts converge into a point that the quality of pharmacy graduates in India is in question and there is a necessity of maintenance of service quality of pharmacy education in the eyes of primary stakeholder namely students. Further, to offer the quality of service in pharmaceutical education, the author needs to measure the same, hence in this research work author has focused on a particular question.

How the pharmaceutical education service quality measured?

Therefore, the author has felt the necessity of reviewing the present state of research works in the field of technical higher education and further develop the research objectives with a more comprehensive understanding of the primarily explored issues. Thus, in the next section of the literature review, the author has presented a brief discussion on education service quality measurement and pharmacy education service quality in a different context of countries and participants.

\section{Literature review}

\section{Higher Education Service Quality Management}

The authors ${ }^{8,10,13-15}$ have delineated the education service with other services like healthcare, bank, telecom and hospitality services. In the case of education service, the interaction between the primary customer (student) and service provider (faculty/administration) are very high and it differs from encounter in form of all other services like healthcare, bank, telecom and hospitality services are having much less encounter both the parties and consequential to this, the chance of reshaping of expectation by reducing it is less. ${ }^{16}$

Service quality literature can be segregated with four schools of thought first one is comprised of those researchers, ${ }^{17}$ who believe a service operation is a 
predominantly encounter / interaction between customer and service provider, especially with the front line service staffs and thus, the relationship building is the key for service satisfaction of the service receiver. The second school of thought is based on the opinion of the Gummesson $(1995)^{18}$ and others ${ }^{19}$ that give an equal focus on service process. In fact, proponent of this school's analyses four stages- Design, Production, Delivery and rational of the service quality. The third one covers the research, writing of Zeithmal, Parasuraman and Berry $(1985,1988,1991),{ }^{20-22}$ Buttle $(1996)^{23}$ and that has mainly measured the quality of service with certain objective methods and parameters. The fourth one in this regard is related to customer satisfaction as an outcome of service quality. Some researchers believe that customer satisfaction is related to service quality, and they are high in number.

How to measure the quality of service? This question has emerged debates among management researchers since the development of 'Service Quality Gap' model. ${ }^{16}$ The measurement of quality of service is always a subject for concern because service is far more complex than that of a product. Only in the case of a few services, quality is anticipated before its consumption. ${ }^{24,25}$ However, in the case of the majority of services, service quality is measured during or after the consumption. ${ }^{26}$ The service is difficult and multifarious since it is intangible, perishable, heterogeneous (dependent on persons involved and the environment) and inseparable (service producer and service consumer are embedded). ${ }^{21}$

According to Gronroos (1982) ${ }^{24}$ and other, ${ }^{27}$ service quality can be measured how delivered service is matched closely with the expectation of the customer. This definition of service quality is elaborated and reemployed further by researcher. ${ }^{20-22,28}$ Infact, they have included a service process and outcome in measuring the quality of the service and offered a process based service quality gap model. ${ }^{20}$ Later, they have also supplemented their initial work by offering five facets of service quality and that is well known as SERVQUAL. ${ }^{21-22,28}$ However, in all cases, their methods of measurement of service quality followed estimating the gap between expected and actual service delivered.

Acceptance of SERVQUAL is widespread since lion shares of service quality research have been carried out in the similar line across the nations. On the other way around, critical evaluation of the SERVQUAL model is also observed and it leads by Cronin and Taylor (1992), ${ }^{29}$ Carman $(1990)^{30}$ and others. ${ }^{23,31,32}$ Critiques namely Carman (1990) ${ }^{30}$ and Cronin and Taylor $(1992)^{29}$ opined that there is very less empirical and conceptual support in favor of considering service quality as a gap between expectation and perception (Actual). Hence, Cronin and Taylor (1992) ${ }^{29}$ carried out a comparison of SERVQUAL and their proposed SERVPERF (performance only measure for service quality)

in terms of empirical survey results. Cronin and Taylor $(1992)^{29}$ have been influenced by opinions of Churchill and Suprenant (1982), ${ }^{33}$ Bolton and Drew (1991) ${ }^{34}$ and other ${ }^{35}$ who preferred comparing actual performance with customer expectations to measure service quality.

Hence, in the review, the principle of measurement of service quality has examined whether perception minus expectation principle has been followed or not (perception of performance-only measure of service quality) by most of the researches in the field of higher education as a service. Here, whether corresponding literature has developed a new construct (measurement items) or not are also presented with the country of origin. Many authors opined specification is more important than generalization ${ }^{16,36}$

After reviewing the literature based on education service management, the author able to draw the reader attention to some key outcomes of the literature as follow.

- There are two different approaches of measurement of service quality in higher education, and these are perception minus expectation (Gap) and perception only.

- The majority of researchers have decided not to go with SERVQUAL constructs rather execute higher education-specific constructs.

- In the Indian context, Mahapatra and Khan $(2000)^{15}$ have proposed a systematic integrated model EduQUAL to understand the level of satisfaction of all stakeholders in the technical education system.

- Another instrument SQM-HEI has been proposed by Senthikumar and Arulraj $(2011)^{5}$ that explained the placement is the main criteria for the parents and the students to select a higher education institute in India. This model has also revealed that the three dimensions- Teaching methodology, Physical Study Resources, and Disciplinary Action, have improved the chances of employability of a student in a higher education institute.

- The researcher has argued that prestigious Bodies like AICTE and UGC should take the initiatives to promote the concept of the industry and institutes' interaction with each other from the primary stage of course designing to the final stage of course completion. 
- Mandal and Banerjee (2012) ${ }^{37}$ have identified three dimensions- Industrial focus, Industrial readiness, and the quality of program aspects of the measurement of engineering program quality.

\section{Pharmaceutical Education Service Quality Measurement}

In the context of pharmaceutical education service quality, Holdford and Reinders ${ }^{9}$ have described the overall service quality as the combination of the functional (process) quality and the technical quality. The functional quality has items related to learning resources, faculty attributes, and the administration whereas technical quality has items related to the intellectual development and mental satisfaction of the students. Whereas $\mathrm{Gu}$ et al. (2016) ${ }^{11}$ have advocated the TQM concept implementation in pharmacy education in China. This study has suggested developing a climate in which the organization can deliver high-quality education. In India, Singh $(2016)^{6}$ has emphasized the extensive implementation of 'Design in Education' (QbDE) in the context of pharmaceutical education. This model elaborates nine elements at the micro-level for the upgradation of overall pharmacy education quality. Moreover, Gupta and Mandal ${ }^{7}$ have identified five dimensions that are required to be improved for the enhancement of the quality of pharmacy education in institutes of India. In summary, the author has searched out seven studies exclusively based on pharmaceutical education and where it has been observed that two authors have constructed a model for education service quality measurement. Mandal and Gupta, $(2018,2019)^{8,10}$ applied different approaches whereas Holdford et al. 2001, 2003,38 have applied different approaches to measure the same.

Finally, after reviewing the literature, the author has identified the three key observations which are as follows:

From a global perspective, a few researchers have identified service quality facets and it is not wise to extend them blindly for measuring service quality gaps of the Indian pharmaceutical education. Thus, it is imperative to call for empirical research to understand the facets of the service quality of pharmaceutical education and to measure the service quality gap of the same.

In the perspective of the Indian environment, the service quality determinants of pharmaceutical education were studied, but not empirically analyzed in each format of educational institutes (Like private University, Government University, Private Institutes) hence, the author has identified a scope to carry out the same in India with empirical justification.
There are two schools of thought regarding the measurement of service quality gap; SERVQUAL measures the gap between perceptions minus expectation of the customers whereas SERVPERF measures the same with performance only.

Therefore, the objective of this study is to identify the comprehensive determinants of pharmaceutical education service quality which apply to all kind of institutes as well as in with any principle of education service quality measurement either it is based on the principle of Perception-only or performance minus expectation (i.e., Gap) measurement.

\section{Methodology}

\section{Questionnaire Development}

The author has considered directly 45 items on the Likert scale which are design by Gupta and $\mathrm{Mandal}^{7}$ and develop a questionnaire for the students as respondents for their expectation from a pharmacy Institute regards to education service quality as well as this questionnaire continues with similar kind of items with regards to the perception or actual service receiving from institutes by students.

\section{Sampling Frame}

The prime objective of this study to provide a model to measure the service quality of the pharmacy education institutes and for that author must consider respondents from across the country India; but physically it is become impossible to conduct this survey. Therefore, the author has set the limit of survey operation within West Bengal since here ninety percent of the students' intake has been made by privately owned institutes for a pharmaceutical graduate program. ${ }^{39}$ Secondly, the state holds seven percent of the Indian population ${ }^{40}$ and almost all Indian population types living here. Therefore, it represents India perfectly. A systematic cluster based random sampling approached is applied to collect the sample. Here in West-Bengal state, there are 24 government and private pharmaceutical institutes, which are having approximately 2000 enrolled students per year under the pharmacy graduate program. ${ }^{29}$ In the data collection process of multi-stage level. In the first stage, 8 out of 24 institutes are selected from two different strata of the institutes grouped into by the parameter of private or government aided. Then in the next stage, the concerned higher authorities of these 8 institutes have been approached with a formal letter to get permission to survey within groups of students. At this stage, the author also asked the authorities about the list of enrolled students in the graduate pharmacy program. From these lists, 4750 students' particular 
have been received and the author has requested 1163 students (983 from private institutes and 180 from government institutes) randomly to participate in the sampling process. As per sample size calculation rules, when the population size is 4750 with a 95 percent confidence interval and with an allowance of 5 percent margin of error minimum size of the sample should be $356 .{ }^{41}$ In fact, the author got full responses from 370 students as the rest did not furnish the questionnaire completely or deny to participate in the sampling process.

\section{Data Collection}

The author has conducted the survey in different stages during the semester classes. During a working break between two classes, the author has approached the respondent. At the same time, I have also offered assistance for explaining statements if any respondent requires the same. In the first stage, the author has offered the first questionnaire to the respondent than after a one-week gap of the initial response, I again met with the same respondent with a second questionnaire for completion of the survey. Purposefully, the author has taken responses about expectation and actual from a respondent in two different times so that responses remain independent of each other. ${ }^{42}$

\section{Research Methods}

To attend the research object of this study, it is necessary to build two exploratory models of education service quality based on relevant service quality items by calculating the gap score that is performance minus expectation and another by performance score (perception-only). The two tests, 'the Bartlett test of Sphericity' and 'KMO test of sample adequacy' are conducted that are required to test before applying the Principal Component Analysis (PCA) technique. The Bartlett test of Sphericity, which is an authentic indicator of the suitability of data for factor analysis, is found to be significant $\left(\chi^{2}=2039.082, \mathrm{~d} f=91, p<0.000\right.$; $\left.\chi^{2}=1313.30, \mathrm{~d} f=91, p<0.000\right)$ respectively in both the cases for perception-only and gap score based models. Again, the Kaiser-Meyer-Olkin (KMO) indexes are 0.664 and 0.709 respectively for both the models that are greater than 0.6 , which is considered adequate for factor analysis. ${ }^{43}$ Thus, both results allow us to proceed further with the principal component analysis (PCA) technique.

\section{Result of PCA with Reliability and Validity}

The principal component analysis explains the existence of four factors with satisfactory variance explained (74.09\% and 68.63\%) in both the cases respectively, which are adequate for further analysis. The internal consistency of each factor is examined with two tests namely Cronbach's alpha and composite reliability (CR) tests. Here, Cronbach's alpha values range from 0.532 to 0.896 and composite reliability (CR) range from 0.722 to 0.912 (Table 1,2).

These values are well acceptable according to the literature references. ${ }^{43,44}$

After that, the results of construct validity have been checked through the variance values of convergent and discriminant validities. The convergent validity is confirmed by Average Variance Extracted (AVE), which is found to be greater than 0.05 in all cases ${ }^{45}$ (Table 1,2). The Discriminant validity criteria have been evaluated by checking the square root of AVE for each construct and that is found to be greater than the inter-correlations with other constructs. Based on the opinion of Gefen et al., ${ }^{46}$ our research has been cleared with the discriminant criteria. The Table 3 and 4 , show the square root values of AVE that is presented in bold is greater than the off-diagonal values of inter-correlation.

\section{The naming of the Dimensions}

In this section, it is important to name the latent factors related to both models. The first dimension comprises six variables (from V1 to V6) and these variables state various scopes for modernization and innovation like the scope for modern laboratory, up-gradation of the library, and entrepreneurial development. Thus, the latent factor that is operating behind is Modern Academic Facilities' and we considered this for the naming of the first dimension. Similarly, the next four variables (from V7 to V10), which are the Industrial training and arrangement of industrial interaction, may be expressed as 'Career Prospective'. The third dimension (V11 and V12) states 'Interdisciplinary Skill' development in the field of sales and marketing as it focuses on marketing study and learning of sales presentation. Last but not the least need of the students is 'Social Status' of Institute of the course and for that they further want more industrial exposure to strengthen their demand.

\section{Confirmatory Factor Analysis}

In the previous sections, one exploratory model was developed in two different approached to measure the pharmaceutical education service quality. Now, in the present section, the author has employed confirmatory factor analysis (CFA) intending to confirm the proposed models (exploratory models). For that purpose, the study utilized absolute, incremental and parsimonious fit criteria (indices). In the Table 5, the details have been shown. 


\begin{tabular}{|c|c|c|c|c|c|}
\hline & Factor Name & $\begin{array}{l}\text { Modern Academic } \\
\text { Facilities }\end{array}$ & $\begin{array}{c}\text { Career } \\
\text { Prospective }\end{array}$ & $\begin{array}{l}\text { Interdisciplinary } \\
\text { Skill }\end{array}$ & $\begin{array}{l}\text { Social } \\
\text { Status }\end{array}$ \\
\hline V1 & $\begin{array}{c}\text { Well-equipped laboratories with adequate } \\
\text { chemicals. }\end{array}$ & 0.892 & & & \\
\hline V2 & Study materials. & 0.844 & & & \\
\hline V3 & Adequate books in library for relevant subjects. & 0.816 & & & \\
\hline V4 & Development verbal and written communication. & 0.790 & & & \\
\hline V5 & $\begin{array}{c}\text { Animal house with adequate* numbers of } \\
\text { species. }\end{array}$ & 0.777 & & & \\
\hline V6 & Faculties for all subjects and specialization. & 0.712 & & & \\
\hline V7 & Industry experts are invited. & & 0.932 & & \\
\hline V8 & Modern computers with the latest software. & & 0.828 & & \\
\hline V9 & Industrial training. & & 0.701 & & \\
\hline V10 & White board along with LCD projector. & & 0.604 & & \\
\hline V11 & Marketing specialized subjects. & & & 0.847 & \\
\hline V12 & $\begin{array}{c}\text { Adequate number of supporting and technical } \\
\text { staffs. }\end{array}$ & & & 0.648 & \\
\hline V13 & $\begin{array}{l}\text { Alumni interaction is possible for industrial skill } \\
\text { development. }\end{array}$ & & & & 0.832 \\
\hline V14 & $\begin{array}{c}\text { College well recognized by my relatives and } \\
\text { friends }\end{array}$ & & & & 0.729 \\
\hline & Total variance explains $(74.09 \%)$ & $32.62 \%$ & $18.25 \%$ & $12.75 \%$ & $10.47 \%$ \\
\hline & Composite Reliability & 0.918 & 0.855 & 0.722 & 0.758 \\
\hline & Cronbach's Alpha (0.817) & 0.896 & 0.782 & 0.539 & 0.548 \\
\hline & Average Variance Extracted (AVE) & 0.612 & 0.569 & 0.603 & 0.651 \\
\hline
\end{tabular}

\begin{tabular}{|c|c|c|c|c|c|}
\hline & Factor Name & $\begin{array}{l}\text { Modern Academic } \\
\text { Facilities }\end{array}$ & $\begin{array}{c}\text { Career } \\
\text { Prospective }\end{array}$ & $\begin{array}{l}\text { Interdisciplinary } \\
\text { Skill }\end{array}$ & $\begin{array}{l}\text { Social } \\
\text { Status }\end{array}$ \\
\hline V1 & Well-equipped laboratories with adequate chemicals. & 0.852 & & & \\
\hline V2 & Study materials. & 0.846 & & & \\
\hline V3 & Adequate books in library for relevant subjects. & 0.777 & & & \\
\hline V4 & Development verbal and written communication. & 0.738 & & & \\
\hline V5 & Animal house with adequate* numbers of species. & 0.732 & & & \\
\hline V6 & Faculties for all subjects and specialization. & 0.672 & & & \\
\hline V7 & Industry experts are invited. & & 0.881 & & \\
\hline V8 & Modern computers with the latest software. & & 0.768 & & \\
\hline V9 & Industrial training. & & 0.735 & & \\
\hline V10 & White board along with LCD projector. & & 0.635 & & \\
\hline V11 & Marketing specialized subjects. & & & 0.804 & \\
\hline V12 & Adequate number of supporting and technical staffs. & & & 0.772 & \\
\hline V13 & $\begin{array}{l}\text { Alumni interaction is possible for industrial skill } \\
\text { development. }\end{array}$ & & & & 0.840 \\
\hline V14 & College well recognized by my relatives and friends & & & & 0.754 \\
\hline & Total variance explains $(68.63 \%)$ & $29.12 \%$ & $18.03 \%$ & $11.14 \%$ & $10.34 \%$ \\
\hline & Composite Reliability & 0.898 & 0.844 & 0.766 & 0.778 \\
\hline & Cronbach's Alpha (0.789) & 0.797 & 0.763 & 0.531 & 0.529 \\
\hline & Average Variance Extracted (AVE) & 0.596 & 0.577 & 0.621 & 0.637 \\
\hline
\end{tabular}


Table 3: Discriminant Validity of Four Factor Model Based on Perception only.

\begin{tabular}{|c|c|c|c|c|}
\hline & MCF & CP & IS & SS \\
\hline MCF & $\mathbf{0 . 7 8 2}$ & & & \\
\hline CP & 0.210 & $\mathbf{0 . 7 5 4}$ & & \\
\hline IS & 0.497 & 0.123 & $\mathbf{0 . 7 7 6}$ & \\
\hline SS & 0.011 & 0.090 & 0.400 & $\mathbf{0 . 8 0 6}$ \\
\hline
\end{tabular}

Note: MAF-Modern Academic Facilities, CP-Career Prospective, IS-Interdisciplinary Skill, SS-Social Status

\begin{tabular}{|c|c|c|c|c|}
\hline & MCF & CP & IS & sS \\
\hline MCF & 0.772 & & & \\
\hline $\mathrm{CP}$ & 0.329 & 0.759 & & \\
\hline IS & 0.315 & 0.172 & 0.788 & \\
\hline SS & 0.387 & 0.142 & 0.019 & 0.798 \\
\hline
\end{tabular}

Note: MAF-Modern Academic Facilities, CP-Career Prospective, IS-Interdisciplinary Skill, SS-Social Status.

\begin{tabular}{|c|c|c|c|c|}
\hline Types of Fit & Model Fit Indexes & Recommended Values & $\begin{array}{l}\text { Model based on } \\
\text { Perception-only } \\
\text { score }\end{array}$ & $\begin{array}{l}\text { Model based } \\
\text { on GAP Score }\end{array}$ \\
\hline & \multicolumn{2}{|c|}{ No. of factors in proposed Model } & 4 factors & 4 factors \\
\hline Goodness of Fit Measure & Chi-Square/df & $\begin{array}{l}\text { Less than } 3.000 \text { for the } \\
\text { nested models }\end{array}$ & 2.880 & 2.780 \\
\hline \multirow{3}{*}{ Absolute Fit Measures } & GFI (Goodness of Fit) & Greater than 0.80 & 0.849 & 0.844 \\
\hline & RMSEA & Less than 0.10 & 0.104 & 0.100 \\
\hline & RMR (Root Mean Square Residual) & Small RMR & 0.016 & 0.017 \\
\hline \multirow{4}{*}{ Incremental Fit Measures } & TLI (Tucker-Lewis Index) & Greater than 0.80 & 0.814 & 0.856 \\
\hline & IFI (Incremental fit index) & Greater than 0.80 & 0.806 & 0.826 \\
\hline & CFI (Comparative Fit Index) & Greater than 0.80 & 0.802 & 0.823 \\
\hline & NFI (Normal Fit Index) & Greater than 0.80 & 0.853 & 0.863 \\
\hline \multirow{2}{*}{$\begin{array}{c}\text { Parsimonious Fit } \\
\text { Measures }\end{array}$} & AGFI (Adjusted GFI) & Greater than 0.80 & 0.823 & 0.883 \\
\hline & PNFI (Parsimonious NFI) & Greater than 0.80 & 0.851 & 0.869 \\
\hline
\end{tabular}

Recommended values $47,4^{8}$

\begin{tabular}{|c|c|c|c|}
\hline \multicolumn{4}{|c|}{ Dependent Variable- Overall satisfaction of students from the pharmaceutical graduate degree course } \\
\hline \multicolumn{2}{|c|}{ Independent variables for Regression analysis } & $\begin{array}{l}\text { Model based on } \\
\text { Perception-only score }\end{array}$ & $\begin{array}{l}\text { Model based on GAP } \\
\text { Score }\end{array}$ \\
\hline \multirow{4}{*}{$\begin{array}{c}\text { All Responded based } \\
\text { Model }\end{array}$} & $\mathrm{R}^{2}$ & 0.517 & 0.507 \\
\hline & Adjusted $\mathrm{R}^{2}$ & 0.483 & 0.465 \\
\hline & Effect Size of Model* & 1.070 & 1.028 \\
\hline & $\begin{array}{c}\text { Variables have a significant coefficient with Overall } \\
\text { satisfaction }\end{array}$ & 10 out of 14 & 10 out of 14 \\
\hline
\end{tabular}

*Effect size measured with Cohen- $\mathrm{d}^{42}$ Measurement $\left[\mathrm{R}^{2} /\left(1-\mathrm{R}^{2}\right)\right]$, Cohen suggested that $\mathrm{d}=0.2$ be considered a 'small' effect size, 0.5 represents a 'medium' effect size and 0.8 a 'large' effect size.

It has been observed from the comparative presentation of the specific indices that model based on gap and perception scores have been demonstrating almost equal kind of goodness of fit.

Furthermore, the author has carried out ordinary least square (OLS) regression, where all the items for measuring service quality in two different models have been considered as independent variables and overall satisfaction of the students from the service quality of that institute has been placed as a dependent variable because overall satisfaction is considered as a goodness of fit parameter of service quality in literature. ${ }^{32,49-51}$
Besides that in this study the coefficient of how many numbers of variables are significantly away from zero are also considered while developing a relationship with overall satisfaction. Based on all mentioned measurements, both the models based on perceptiononly and gap scores are at par the level of satisfaction. With an objective to analyse, two OLS results measure namely $\mathrm{R}^{2}$ (goodness of fit), Adjusted $\mathrm{R}^{2}$ (adjusted with a degree of freedom; more parsimonious) and effect size (ratio between variance explained and variance unexplained by model) proposed by Cohen (1992), ${ }^{52}$ have been calculated (Table 6). Overall, the output 
observed contrary statistical outcome though on a deeper level it unfolds the same thoughtful insight. In the next section, these are explained thoroughly.

\section{DISCUSSION OF RESULTS}

The outcome of this study finally can be discussed in the following points.

Based on the two different types of modelling, it is seen that the Gap score (P-E) based pharmaceutical education service quality model is almost equal in performance in comparison with perception-only score based model for a similar purpose.

In the case of criterion variable (overall satisfaction) linked model 'perception-only score' based pharmaceutical education service quality model have shown slightly (insignificantly) higher performance over 'Gap-score' based model of identical purpose. Thus, the efficacy of two different pharmaceutical education service quality models is almost equal with these 14 variables.

This result will help to infer that the application of the gap score based evaluation of service quality (SERVQUAL orientation) or perception-only measures (SERVPERF orientation) with these 4 factors including 14 variables does not change the output. Hence, the study concludes that service quality if measured by the student, it is evidenced that the approach with perception-only score (SERVPERF orientation) or gap (P-E) score (SERVQUAL orientation) does not change the outcome of the result.

\section{CONCLUSION AND FUTURE SCOPE}

It is customary to conclude the study with its outcome that may be relevant for existing academics, industry and society. This research work has delivered some of the important outcomes. The first one is comprehensive determinants for measuring the pharmaceutical education service quality in India. The Present study offers four facets of a comprehensive model that are not directly common with literature. Comparing with two of the relevant works of Holdfold and Reinder ${ }^{9}$ and Holdfold and Patker, ${ }^{38}$ present research deviates at least with three factors namely 'Modern Academic Facilities' (more majorly option for higher study), Interdisciplinary Skill' (whether they can be chosen as marketing executive or not) and 'Social Status' of the institute. These three facets represent the economic uncertainty of Indian youth and social approval for higher academic degree holders in Indian society. It is predominantly Indian culture-specific therefore not common with works based on respondents of western nations. Holdfold and Reinder ${ }^{9}$ and Holdfold and Patker ${ }^{38}$ have focused on 'Career driven facilities', which is common with present work as 'Career Prospective' facet. Indian based researchers like Singh ${ }^{6}$ have identified 'Annual job opportunities' that is the same as 'Interdisciplinary Skill' in present research work. Two dimensions like 'Modern Academic Facilities' and 'Social Status' are identified as a new one (Not mentioned in the literature) in the context of pharmaceutical education, but these are related to other higher education service quality measurement models of Joseph and Joseph. ${ }^{42}$ Moreover, both facets are matched with the Indian economic environment that promotes the economic value and multiple job readiness of Indian people due to the competitiveness of the market.

This clearly manifests satisfaction is correlated uniformly with gap score and performance score for the responses gathered from all institutes. It unfolds the fact the researcher can calculate or measure the education service quality of pharmacy institutes by any approach of service quality measurement with these 14 variables. Though this study is enough to explain a major part of service quality of any pharmacy institute in India, yet it has some limitation of based on West Bengal, state of India. The author firmly believe that this study has further scope of improvement to extend this study to other region of country.

\section{ACKNOWLEDGEMENT}

The author also acknowledges the support of respondents and pharmacy institutes' authorities of West Bengal, India.

\section{CONFLICT OF INTEREST}

The authors declare no conflict of interest.

\section{ABBREVIATIONS}

PEIs: Pharmaceutical Education Institutes; PCA: Principal Component Analysis; HEI: Higher Education Institute; AICTE: All India Council for Technical Education; UGC: University Grants Commission.

\section{REFERENCES}

1. Anderson L, Ostrom AL, Corus C, Fisk RP, Gallan AS, Giraldo M, Mende M, Mulder M, Rayburn SW, Rosenbaum MS, Shirahada K, Williams JD. Transformative service research: an agenda for the future. J Bus Res. 2013;66(8):1203-10. doi: 10.1016/j.jbusres.2012.08.013.

2. Akhavan Kazemi M. Higher education and stable political development. Inst Res Plan Higher Educ. 2005;1:13-32. 
3. Bin Saleh GB, Rezk NL, Laika L, Ali A, El-Metwally A. Pharmacist, the pharmaceutical industry and pharmacy education in Saudi Arabia: a questionnaire-based study. Saudi Pharm J. 2015;23(5):573-80. doi: 10.1016/j.jsps.2015.02.019, PMID 26594125.

4. Alam GM, Al-Amin AQ. Role of pharmacy education in national development of Bangladesh: A Scope for public and private sectors. Indian J Pharm Educ Res. 2014;48(4):11-21. doi: 10.5530/ijper.48.4.3.

5. Senthilkumar N, Arulraj A. SQM-HEI - determination of service quality measurement of higher education in India. J Modell Manag. 2011;6(1):60-78. doi: 10.1108/17465661111112502.

6. Singh S. Quality by Design in Education (QbDE)-A Possible Futuristic Approach to Improve Current Status of Pharmaceutical Education in India. Indian J Pharm Educ Res. 2016;50(1):39-45. doi: 10.5530/ijper.50.1.6.

7. Gupta $\mathrm{H}$, Mandal $\mathrm{K}$. In search of service quality gap in pharmaceutical education: an alternative approach. Int J Appl Bus Econ Res. 2016;14(12):8508-83.

8. Mandal K, Gupta H. Service quality gap measurement in pharmaceutical educational institutes: an empirical analysis for model development. Indian J Pharm Educ Res. 2018;52(3):351-62. doi: 10.5530/ijper.52.3.41.

9. Holdford D, Reinders TP. Development of an instrument to assess student perceptions of the quality of pharmaceutical education. Am J Pharm Educ. 2001;65(2):125-31.

10. Mandal K, Gupta H. Gap versus performance based measure of pharmaceutical education service quality: an empirical comparison. Indian J Pharm Educ Res. 2019;53(3):421-34. doi: 10.5530/ijper.53.3.75.

11. Gu X, Dong M, Sun H, Li J, Liu G, Wu J, Hao F, Li Y Implementation of Total Quality Management in Higher Pharmaceutical Education: Opportunity and Challenge. Indian J Pharm Educ Res. 2016;50(1):34-8. doi: 10.5530/ ijper.50.1.5.

12. Abdullah F. HEdPERF versus SERVPERF: the quest for ideal measuring instrument of service quality in higher education sector. Qual Assur Educ. 2005;13(4):305-28. doi: 10.1108/09684880510626584.

13. Gallifa J, Batallé P. Student perceptions of service quality in a multi-campus higher education system in Spain. Qual Assur Educ. 2010;18(2):156-70. doi: 10.1108/09684881011035367.

14. Angell RJ, Heffernan TW, Megicks P. Service Quality in postgraduate education. Qual Assur Educ. 2008;16(3):236-54. doi: 10.1108/09684880810886259.

15. Mahapatra SS, Khan MS. A framework for analysing quality in education settings. Eur J Eng Educ. 2007;32(2):205-17. doi: 10.1080/03043790601118606.

16. Carrillat FA, Jaramillo F, Mulki JP. The validity of the SERVQUAL and SERVPERF scales: A meta-analytic view of 17 years of research across five continents. Int J Serv Ind Manag. 2007;18(5):472-90. doi: 10.1108/09564230710826250.

17. Williams C, Buswell J. Service Quality in leisure and tourism. CABI Publishing; 2003.

18. Gummesson E. Truths and Myths in Service Quality. Int J of Service Industry Mgmt. 1991;2(3):7-16. doi: 10.1108/09564239110007256.

19. Edvardsson B. Service Quality improvement. Managing service quality: an [international journal:1998];8(2):142-9.

20. Zeithaml VA, Parasuraman A, Berry LL. Problems and strategies in services marketing. J Mark. 1985 Mar;49(2):33-46. doi: 10.1177/002224298504900203.

21. Parasuraman A, Zeithaml VA, SERVQUAL BL. A multiple-item scale for measuring consumer perceptions of service quality. 1988;64(1):12-40.

22. Parasuraman A, Berry LL, Zeithaml VA. Understanding customer expectations of service. Sloan Manag Rev. 1991;32(3):39-48.

23. Buttle F [review]. SERVQUAL: review, critique, research agenda. Eur J Mark. 1996;30(1):8-32. doi: 10.1108/03090569610105762.

24. Gronroos C, Service quality. The six criteria of good perceived service. Rev Bus. 1988;9(3):10.

25. Jiang JJ, Klein G, Crampton SM. A note on SERVQUAL reliability and validity in information system service quality measurement. Decis Sci. 2000;31(3):725-44. doi: 10.1111/j.1540-5915.2000.tb00940.x.
26. Gounaris SP. Trust and commitment influences on customer retention: insights from business-to-business services. J Bus Res. 2005;58(2):126-40. doi: 10.1016/S0148-2963(03)00122-X.

27. LeBlanc $\mathrm{G}$, Nguyen N. Customers' perceptions of service quality in financial institutions. Int J Bank Mark. 1988;6(4):7-18. doi: 10.1108/eb010834.

28. Parasuraman A, Zeithaml VA, Berry LL. Reassessment of expectations as a comparison standard in measuring service quality: implications for further research. J Mark. 1994;58(1):111-24. doi: 10.1177/002224299405800109.

29. Cronin Jr JJ, Taylor SA. Measuring service quality: a reexamination and extension. J Mark. 1992;56(3):55-68. doi: 10.1177/002224299205600304.

30. Carman JM. Consumer perceptions of service quality: an assessment of T. Journal of retailing. 1990;66(1):33.

31. Brady MK, Cronin Jr JJ, Brand RR. Performance-only measurement of service quality: a replication and extension. J Bus Res. 2002;55(1):17-31. doi: 10.1016/S0148-2963(00)00171-5.

32. Lam SSK. SERVQUAL: A tool for measuring patients' opinions of hospital service quality in Hong Kong. Total Qual Manag. 1997;8(4):145-52. doi: 10.1080/0954412979587.

33. Churchill Jr GA, Surprenant C. An investigation into the determinants of customer satisfaction. J Mark Res. 1982;19(4):491-504. doi: 10.1177/002224378201900410.

34. Bolton RN, Drew JH. A multistage model of customers' assessments of service quality and value. J Con Res. 1991;17(4):375-84. doi: 10.1086/208564.

35. Woodruff RB, Cadotte ER, Jenkins RL. Modeling consumer satisfaction processes using experience-based norms. J Mark Res. 1983;20(3):296-304. doi: $10.1177 / 002224378302000308$.

36. Ladhari R. A review of twenty years of SERVQUAL research. Int J Qual \& Service Sciences. 2009;1(2):172-98. doi: 10.1108/17566690910971445.

37. Mandal K, Banerjee CK. A search for measuring quality in engineering education: an empirical study. ZENITH Int J Bus Econ Manag Res. 2012;2(3):50-67.

38. Holdford D, Patkar A. Identification of the service quality dimensions of pharmaceutical education. Am J Pharm Educ. 2003;67(4):108. doi: 10.5688/ aj6704108.

39. Pharmacy college data. Available from: http://www.aicte-india.org/dashboard/ pages/dashboardaicte.php [cited 23/9/2021]. [Last cited on May 2020].

40. India Population Census provisional population totals. New Delhi: Office of the Registrar General and Census Commissioner; 2011. [ Last cited on May 2020].

41. Sample size calculation. Available from: http://research-advisors.com/tools/ SampleSize.htm [cited 23/9/2021]. [ Last cited on May 2020].

42. Joseph M, Joseph B. Service Quality in education: a student perspective. Qual Assur Educ. 1997;5(1):15-21. doi: 10.1108/09684889710156549.

43. Hair J, Black B, Babin B, Anderson R, Tatham R. Multivariate data analysis. 7th ed. Englewood Cliffs: Prentice Hall; 2009. p. 97-125.

44. Nunnally CJ. Psychometric theory. New York: McGraw-Hill Book Co.1978.

45. Bajpai N. Business research methods. London: Pearson Education; 2011.

46. Gefen D, Straub D, Boudreau MC. Structural equation modeling and regression: guidelines for research practice. Commun Assoc Inf Syst. 2000;4(1):7. doi: 10.17705/1CAIS.00407.

47. Awang Z. A handbook on SEM. Struct Equ Model. 2012.

48. Awang Z, Wan Afthanorhan WMA, Asri MAM. Parametric and nonparametric approach in structural equation modeling (SEM): the application of bootstrapping. Mod Appl Sci. 2015;9(9):58. doi: 10.5539/mas.v9n9p58.

49. Mehta SC, Lalwani AK, Li Han S. Service Quality in retailing: relative efficiency of alternative measurement scales for different productservice environments. Int J Retail Distrib Manag. 2000;28(2):62-72. doi: 10.1108/09590550010315106.

50. Smith AK, Bolton RN, Wagner J. A model of customer satisfaction with service encounters involving failure and recovery. J Mark Res. 1999;36(3):356-72. doi: 10.1177/002224379903600305.

51. Angur MG, Nataraajan R Jr, Jahera JS. Service Quality in the banking industry: an assessment in a developing economy. Int J Bank Mark. 1999;17(3):116-25. doi: 10.1108/02652329910269211. 
PICTORIAL ABSTRACT

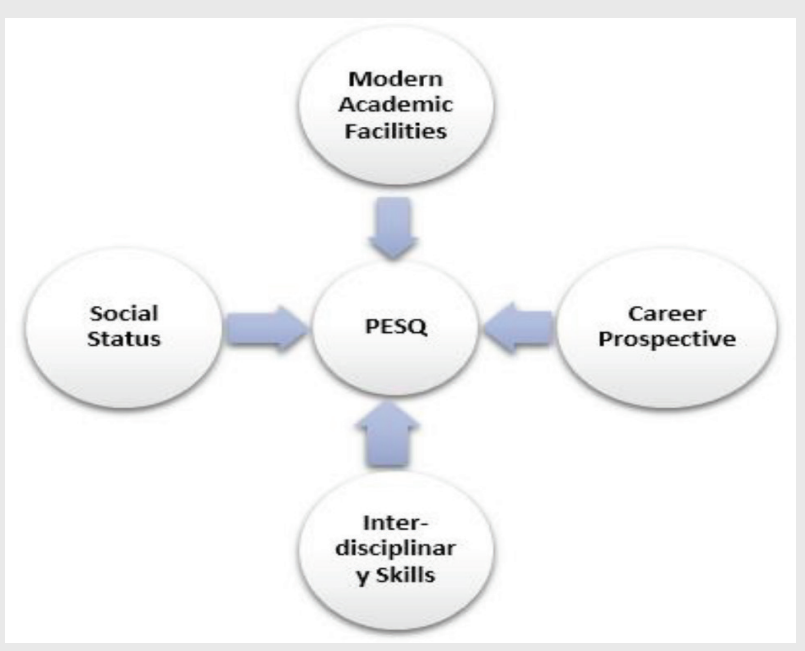

\section{SUMMARY}

- Build a comprehensive model to measure the service quality of the pharmaceutical institutes in India.

- This model is developed with the help of 14 variables under 4 latent factors of education service quality.

- This model might provide a road map to the Government for improving the quality of education in the pharmacy education system.

\section{About Authors}

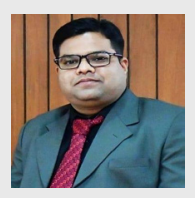

Dr. Hemant Gupta is associated with Alliance University Bangalore as Assistant Professor Marketing. He holds the Ph.D. degree from National Institute of Technology Durgapur and master's in business management from University of Calcutta. His area of research is Pharmacy education in India.

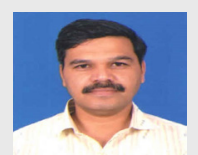

Dr. Bhavesh Parmar, Having more than 16 years of teaching an industry experience. Presently working as a Assistant Professor at Indukaka Ipcowala Institute of Management (I2IM), CHARUSAT University.

His area of Specialization in Marketing, Consumer Behaviour, Services Marketing \& Entrepreneurship.

Cite this article: Gupta H, Parmar BJ. The Measurement Model of the Pharmacy Education Service Quality: An Empirical Quest Based on Two Approaches. Indian J of Pharmaceutical Education and Research. 2021;55(4):94756. 